\title{
Effect of four teaching strategies on senior secondary students' achievement in an aspect of agricultural science
}

\author{
Olatoye R. A \& Adekoya, Y. M.1
}

\begin{abstract}
This study investigated the effect of four teaching strategies; peer-tutoring, demonstration, project-based and lecture teaching strategies on students' achievement in pasture and forage crops which is an aspect of agricultural science. Lecture strategy served both as a teaching strategy as well as control since it is assumed to be a conventional strategy of teaching. A $4 \times 2 \times 2$ pre-test, post-test experimental design with a control group was used in which two hundred randomly selected Senior Secondary School II (SSS II) Agricultural Science students were drawn from three schools. The data was analyzed using ANCOVA and Scheffe post-hoc analysis. There was significant main effect of treatment on students' achievement in an aspect of agricultural science that is, pasture and forage crops [F3, $183=20.775 ; \mathrm{p}<0.05]$. Also, students performed significantly at different levels in the three groups. There was no significant interaction effect of treatment and gender on students' achievement in an aspect of agricultural science that is, pasture and forage crops [F3, $183=0.404 ; p>0.05]$. Peer-tutoring, demonstration and project-based strategies of teaching are potent in raising students' achievement. Thus, inservice training in form of workshops, seminars and symposia should be organized for teachers regularly to update their knowledge on adoption of appropriate teaching strategies.
\end{abstract}

Keywords Peer-tutoring, demonstration, project, lecture, teaching strategies, pasture and forage crops.

\section{Introduction}

It is now being recognized that there are better ways to learn than through the traditional methods (Wood \& Gentile, 2003). Educators are beginning to show an increased awareness of the importance of the way students learn. Many of the standard methods of conveying knowledge have been shown to be relatively ineffective on the students' ability to master and then retain important concepts. Learning through some methods of teaching is passive rather than active. The traditional methods (lecture, laboratory, recitation) do not tend to foster critical thinking, creative thinking, and collaborative problem-solving.

With many countries striving to educate all their citizens, education professionals are seeking research-supported practices that are applicable in classrooms and can facilitate students' access to the mastering of concepts in agricultural science. There is therefore the need to introduce

1 Olatoye R. A lectures at Department of Science, Technology and Mathematics Education, College of Education, Ipetu-Ijesa Campus, Osun State University, Osogbo, Osun State, Nigeria. E-mail: kingdemola@yahoo.com. Adekoya, Y. M. also lectures at the Institute of Education, Faculty of Education, Olabisi Onabanjo University, Ago-Iwoye, Ogun State, Nigeria. E-mail:olarayo200888@yahoo.com 
Effect of four teaching strategies on senior secondary students' achievement in an aspect of agricultural science Olatoye R. A \& Adekoya, Y. M.

modern instructional strategies- peer-tutoring, demonstration and project-based strategies that do not only create cooperative pleasant atmosphere but enhance peer relations and also increase academic achievement of students (Prpric \& Hadgraft, 2009).

The project-centered learning approach (or more commonly, "Project-Based Learning", PBL) has been extensively applied and found effective in science, legal and medical education as well as engineering. A substantial body of literature supports the thesis that PBL substantially improves long-term retention, "deep understanding" and ability to extrapolate scientific knowledge to subsequent learning experiences and new situations (Barron et al, 1998, Blumenfeld, Soloway, Marx, Krajcik, Guzdial \& Palincsar, 1991; Williams 1992 \& Bransford, \& Schwartz, 1999). The application of this approach to the study of certain concept is motivated by several factors derived both from the research literature and teaching experience. Binnie (2002) concluded in a paper that the use of projects was very helpful in assisting the learning of the students. He stressed that students' active involvement in the tasks forced them to think and enhanced their learning. The use of real data of their own choice motivated them because they wanted to know what conclusions they might come to. Without the projects their understanding of the process of problem-solving using the statistical thinking strategy outlined would have been very theoretical.

Project work approach seems to have the components to motivate teachers and students to develop a cooperative work mainly aiming at the students to perceive and understand all the necessary stages required to arrive at logical conclusion (Biajone, 2006). Project-based Learning is a systematic teaching method that engages students in learning, knowledge and skills through an extended inquiry process structured around complex, authentic questions and carefully designed products and tasks. Research shows that learners not only respond by giving useful information, but they also actively use what they know to explore, negotiate, interpret and create. Education has benefited from this teaching strategy, as teachers have learned how to effectively select content and activities to amplify and extend the skills and capabilities of students.

No one can deny that schools are becoming diverse in terms of student backgrounds and abilities, and teachers are being ever more challenged to find effective ways to meet diverse needs of their students. Educators confront classrooms in which students' exhibit assorted academic and behavioural characteristics and they are increasingly looking for successful instructional and classroom management techniques (Tournaki \& Crisccitiello, 2003). Project-Based Learning (PBL) has emerged to become an instructional approach that is gaining growing interest within the engineering education community (Hadim \& Esche, 2002). Holubara (2008) described PBL as: "An instructional method that challenges students to 'learn how to learn,' working cooperatively in groups to seek solutions to real world problems". Prpic and Hadgraft (2009) addressed the key ingredients of PBL and postulate that it should not be confused with design projects or case studies where the focus is predominantly on the application of existing knowledge and integration of what is already known. PBL goes beyond this, students will encounter some concepts for the first time and therefore they need strategies for acquiring this new knowledge. Hence, teachers have begun to take a closer look at project strategy of teaching as a tool in their array of teaching techniques. Holubara (2008) reported that project-based teaching strategy leads to team work; students learn to work as researchers, with various tools, 
technologies and materials. He submitted that project-based strategy is one of the most effective strategies for teaching science for understanding.

Another method of teaching, demonstration method has been shown to be effective with both large and small groups. The greater the degree of participation and sensory involvement by the learner, the more effective learning will be. Carrier (2005), Newly, Stepich, Lehman and Russel (1996) identified ways teacher can improve the use of demonstration method in the classroom. They suggest that teacher should allow students to use several senses by allowing them to see, hear and possibly experience. Also, ideas should be presented to stimulate interest. If these precautionary measures are not taken, demonstration can limit student participation.

Uhumuavbi and Mamudu (2009) found that demonstration method of teaching is sensitive to gender. They reported that exposing students to demonstration method yielded a better performance for male students than their female counterparts. It is therefore necessary to verify such claim. In this study gender is one of the moderating variables because it is important to find out if the treatments are sensitive to gender. Instructional strategies are tools for reaching the set goals and objectives. The effective teacher has many teaching methods at his or her disposal and can select the ones that will be most effective for leading the learner to the desired behaviours. The level of students' performance in the internal and external examinations cannot improve until teachers are able to employ appropriate strategies to impact desired knowledge and skills on the learners.

The understanding of peer-tutoring adopted in this study is similar to the description of peertutoring or peer-learning by Bond, Cohn and Sampson (2001). They define peer-tutoring as involving students' learning from and with each other in ways which are mutually beneficial and involve sharing knowledge, ideas and experiences among participants. The emphasis is on the learning process, including emotional support that learners offer one another, as much as the learning itself. Peer-tutoring has been shown to be effective even in teaching students identified as learning disabled (Telecsan, Slaton \& Stevens, 1999).Peer-tutoring has also been demonstrated to be effective irrespective of student level or grade.

According to Longareth, Godinho, Parr and Wilson (2009), peer-tutoring enhances motivation, improved cognition and social outcomes in learning, increased sense of responsibility for one's own learning and improved metacognitive skills. However, Boud et al (2001) showed that students who resisted the peer-tutoring experience referred to dissatisfaction about the uneven distribution of workload among members in the group. Some students argued that the class time spent on peer-tutoring was at the expense of teaching the course content. Longaretti et al (2009) suggested having smaller groups to reduce potential for serious conflict, less place for individual to 'hide' in the process, allowing students to choose topics that interest them and readiness of the teacher to assist at every point.

Gender has remained a burning issue and has also remained relevant in education because it has been linked to achievement and participation in certain professions (Sotonade, 2004). Certain cultures restrict particular gender to certain professions like farming, engineering and trading (Erinosho, 1997; Olatoye \& Afuwape, 2004). Therefore, using gender as a moderating variable in an experimental study can yield useful practical information. However, there have been conflict findings on how gender influences academic achievement. It seems the influence of 
gender varies according to school subjects. For example, while Olatoye (2008) reported there is no significant difference between male and female achievement in science. Tamir (1990) reported there is no significance difference between male and female achievement in biology and chemistry but reported a significant difference in physics (boys scoring higher).

Kumar and Morris (2005) advocated for consideration of gender in studies involving achievement and scientific understanding in the biological and physical sciences. Lee (1998) observed that educators perhaps unknowingly had for many decades considered reading and literature as female domains and mathematics and science as male domains. While understanding the need to address gender difference represents a vital step, making education genderresponsive will require a genuine commitment to provide teaching -learning experiences that reflect female and male difference. Lee further noted that males tended to do much better in the physical sciences (like physics), while females held a modest advantage in the life science (like biology and agricultural science). Johnson, Wardlow and Franklin (1998) found that student achievement in Agricultural science is not influenced by gender.

Sanhez and Roda (2006) defined self-concept as the set of knowledge and attributes, that a person has about himself or herself; the perception an individual assigns to herself/himself, the characteristics or attributes that a person uses to describes himself or herself .In experimental studies, there is normally social interaction among the students themselves and between the students and their teacher. It is therefore important to consider a moderating variable like selfconcept which may influence student interaction and possibly achievement in the class. Selfconcept is a strong predictor of student academic achievement (Olatoye, 2008; Lang, 2006). Also, self-concept can be developed or constructed by individuals through interaction within the environment and reflecting on that interaction (Huitt, 2004). Thus self-concept is a variable that can be enhanced in students through conscious efforts of the teacher and counsellor. Including a moderating variable like this is this in the study will enable teachers and experts in the field know if the treatment is sensitive to self-concept or not and enhance precautionary measures they should take in adopting the teaching strategies. Olatoye (2008) asserted that any student characteristics that can change because of training and exposure to counselling can be very important in enhancing students' academic achievement.

Also, the importance of science and technology in the growth and development of any nation cannot be over emphasized and it is apparent that technology cannot thrive without using appropriate instructional teaching strategies to teach the students. This is because future development of any nation in the fields of sciences depends on how well the science subjects are taught. It is against this backdrop that experimental investigation into effect of four different methods of teaching (project, demonstration, peer-tutoring and lecture) on senior secondary school students' achievement in pasture and forage crops (an aspect of agricultural science) becomes imperative.

\section{Research Hypotheses}

The following research hypotheses were formulated for the study:

$\mathrm{H}_{\mathrm{O} 1}$ : There is no significant main effect of treatment on students' achievement in an aspect of agricultural science (pasture and forage crops) 
$\mathrm{H}_{\mathrm{O} 2}$ : There is no significant main effect of gender on students' achievement in an aspect of agricultural science (pasture and forage crops)

$\mathrm{H}_{\mathrm{O} 3}$ : There is no significant main effect of self-concept on students' achievement in an aspect of agricultural science (pasture and forage crops)

$\mathrm{H}_{\mathrm{O} 4}$ : There is no significant main effect of treatment and gender on students' achievement in an aspect of agricultural science (pasture and forage crops)

$\mathrm{H}_{\mathrm{O} 5}$ : There is no significant interaction effect of treatment and self-concept on students' achievement in an aspect of agricultural science (pasture and forage crops)

$\mathrm{H}_{\mathrm{O} 6}$ : There is no significant interaction effect of gender and self-concept on students' achievement in an aspect of agricultural science (pasture and forage crops)

$\mathrm{H}_{\mathrm{O} 7}$ : There is no significant interaction effect of treatments (demonstration, project-based and peer-tutoring teaching strategies), gender and self-concept on students' achievement in an aspect of agricultural science (pasture and forage crops)

\section{Methodology}

\section{Research Design}

A 4x2x2 pre-test, post-test randomized factorial group design was used for the study in which there were three experimental groups and one control group. Self-concept and gender were used as moderating variables. The same pre-test was initially administered to the agricultural science students in the four groups before the treatment. Peer-tutoring strategy was used in the first group, demonstration strategy was used in the second group; project-based strategy was used in the third group while the lecture strategy was adopted in the fourth group which served as control. At the end of the six-week treatment, a post-test was conducted in these four groups.

Table 1: Randomized control-Group Pre-test Post-test Design

\begin{tabular}{llll}
\hline Group & Pre-test & Treatment & Post-test \\
\hline $1^{\text {st }}$ Experimental Group & $\mathrm{O}_{1 \mathrm{D}}$ & $\mathrm{X}_{\mathrm{D}}$ & $\mathrm{O}_{2 \mathrm{D}}$ \\
$2^{\text {nd }}$ Experimental Group & $\mathrm{O}_{1 \mathrm{P}}$ & $\mathrm{X}_{\mathrm{P}}$ & $\mathrm{O}_{2 \mathrm{P}}$ \\
$3^{\text {rd }}$ Experimental Group & $\mathrm{O}_{1 \mathrm{Pr}}$ & $\mathrm{X}_{\mathrm{Pr}}$ & $\mathrm{O}_{2 \mathrm{Pr}}$ \\
Control Group & $\mathrm{O}_{1 \mathrm{~L}}$ & & $\mathrm{O}_{2 \mathrm{~L}}$ \\
\hline
\end{tabular}

Where:

$\mathrm{O}_{1 \mathrm{D}}$ represents the pre-test scores for demonstration teaching strategy group ( $1^{\text {st }}$ experimental group) $\mathrm{O}_{2 \mathrm{D}}$ represents the post-test scores for demonstration teaching strategy group ( $1^{\text {st }}$ experimental group) $X_{D}$ represents the treatment for demonstration teaching strategy group $\left(1^{\text {st }}\right.$ experimental group) $\mathrm{O}_{1 \mathrm{p}}$ represents the pre-test scores for peer-tutoring teaching strategy group $\left(2^{\text {nd }}\right.$ experimental group) $\mathrm{O}_{2 \mathrm{p}}$ represents the post-test scores for peer-tutoring teaching strategy group ( $2^{\text {nd }}$ experimental group) $X_{p}$ represents the treatment for peer-tutoring teaching strategy group $\left(2^{\text {nd }}\right.$ experimental group) $\mathrm{O}_{1 \mathrm{pr}}$ represents the pre-test scores for project-based teaching strategy group (3rd experimental group) $\mathrm{O}_{2 \mathrm{Pr}}$ represents the post-test scores for project-based teaching strategy group (3rd experimental group) $\mathrm{X}_{\mathrm{Pr}}$ represents the treatment for project-based teaching strategy group (3rd experimental group) $\mathrm{O}_{1 \mathrm{~L}}$ represents the pre-test scores for control group strategy

$\mathrm{O}_{2 \mathrm{~L}}$ represents the post-test scores for control group strategy 
Effect of four teaching strategies on senior secondary students' achievement in an aspect of agricultural science Olatoye R. A \& Adekoya, Y. M.

Table 2: Purposive Randomized control-Group Pre-test-Post-test Design

\begin{tabular}{lcc|ccc}
\hline & \multicolumn{2}{c|}{ Male } & \multicolumn{3}{c}{ Female } \\
\cline { 2 - 5 } & $\begin{array}{c}\text { High Self- } \\
\text { concept }\end{array}$ & $\begin{array}{c}\text { Low Self- } \\
\text { concept }\end{array}$ & $\begin{array}{c}\text { High Self- } \\
\text { concept }\end{array}$ & $\begin{array}{c}\text { Low Self- } \\
\text { concept }\end{array}$ & Total \\
\hline Peer-tutoring & 13 & 13 & 13 & 13 & 52 \\
Demonstration & 13 & 13 & 13 & 13 & 52 \\
Project-based & 13 & 13 & 13 & 13 & 52 \\
Control & 13 & 13 & 13 & 13 & 52 \\
Total & 52 & 52 & 52 & 52 & 208 \\
\hline
\end{tabular}

\section{Target Population and Sample}

The population for this study comprised of all Senior Secondary School two (SS II) agricultural science students in Ijebu-Ode Local Government Area of Ogun State. A total of two hundred Senior Secondary School two (SSS II) students purposively selected from the four schools constituted the sample for the study. Fifty two students (representing the number in a group) were selected from each school. The schools were purposively selected so that they would be far apart enough not to allow interference.

\section{Research Instruments and their Validation}

The instruments used for the study are: Teaching manual on pasture and forage crops, common grasses and legumes samples, grasses and legumes album, self-concept questionnaire as well as a twenty-item objective achievement test used for the pre-test, post-test tagged Agricultural Achievement Test (AAT).

The research instruments used for the pretest, post-test was tagged Agricultural Achievement Test (AAT) 1 and 2.Items were generated from the West African Examinations Council (WAEC) and National Examinations Council (NECO) Agricultural Science past questions.

Despite using standardized items from these popular national examination bodies, the selected items on pasture and forage crops were still given to experienced teachers for critique and suggestions. This led to the modification and rejection of some items. Prior to the commencement of the experiment, the test items were administered to fifty non-participating students but of the same cultural background and also offering agricultural science as a subject. This was done to determine the consistency of the items. The test was administered twice with two weeks interval on these 50 students who did not participate in the major study. Thus, a testretest reliability coefficient of 0.78 was obtained for the achievement test. Similarly, a testretest reliability co-efficient of the self-concept questionnaire is 0.714 .

\section{Data Collection Procedure}

The research involved two main stages, which were the administration of pre-test and post-test that contained the same items arranged in different order. The study was conducted for a period of six weeks during which the topic, pasture and forage crops was covered. The pre-test was administered in the first week of the research exercise to the whole students before the experimental groups were subjected to treatments. All the practical sessions were held on the school farm with the materials provided by the schools. Six students dropped out before the posttest was administered making the sample size to drop from 156 to 150. 
After the administration of the pre-test, students in all the groups, they were taught various aspects of the topic; pasture and forage crops. Below are the details of breakdown of topics into weeks:

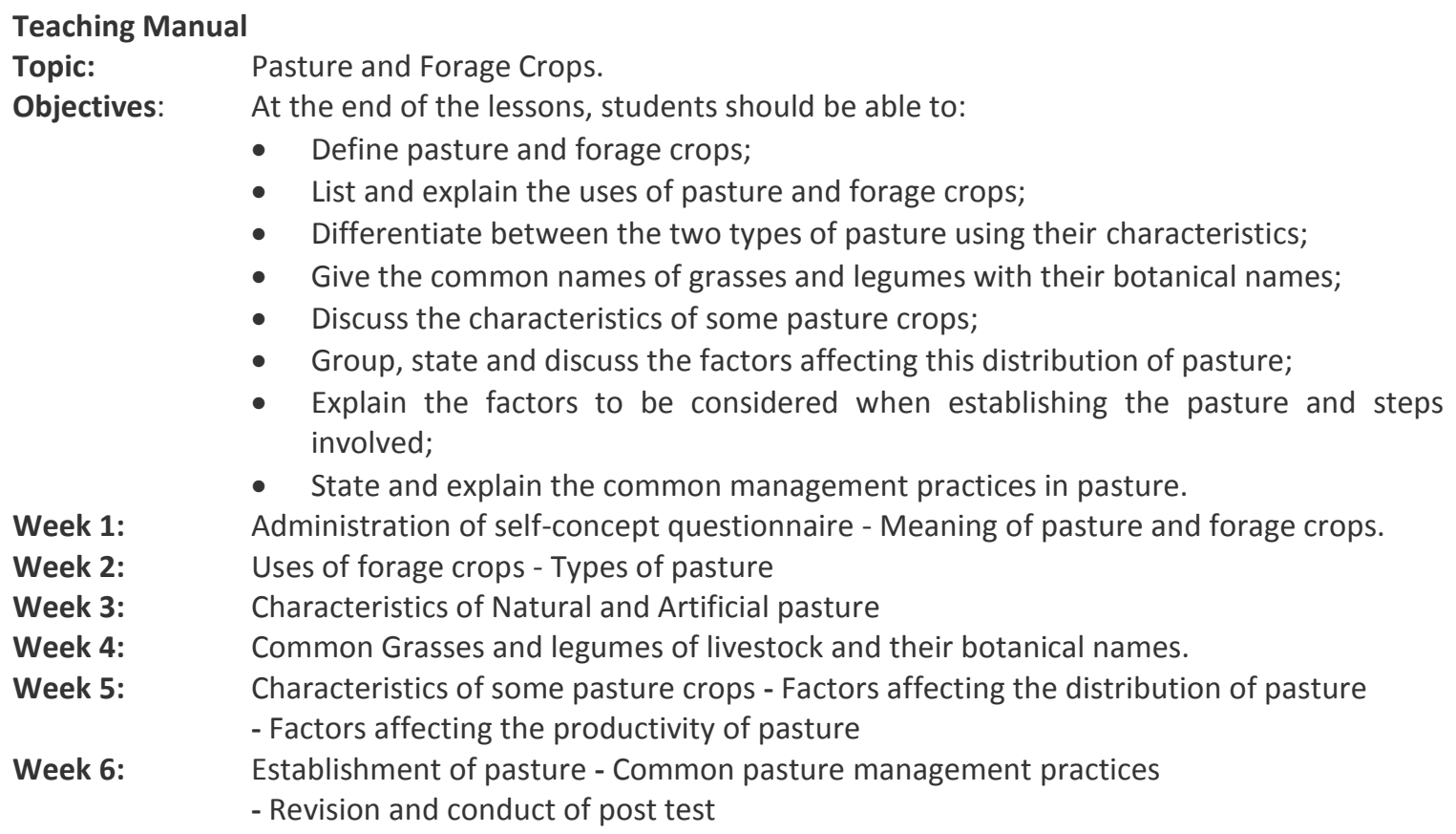

Students in the first group (demonstration method) were given one week to read about the topic and make the list of materials and specimens required for the experiments. The group was divided into eight sizable sub-groups on the school farm to make demonstration by the teacher meaningful. Two practical exercises were carried out in a week. The researcher used samples of grasses and legumes on the school farm, models of different grass vegetations to demonstrate their characteristic features to the students on the farm. Questions were entertained during the practical sessions from the students.

The second group was exposed to peer-tutoring teaching strategy during the weeks of the research exercise. Students in this group were always asked to read ahead about the topics and make list of specimens required for the experiment. The group which comprised 52 students was divided into eight sub-groups, each sub-group comprising of between 6 and 7 students. The tutor give basic explanation of the topics and later thoroughly engage the students to teach themselves in the sub-groups while the tutor was also available to direct discussion and provide further explanation when necessary.

The third group (project method) was exposed to project-based teaching strategy whereby students made album showing pictures of pasture and forage crops. The students in this group also wrote on topics of interest in any aspect pasture and forage crops and also make oral presentation. When the project topics were completed, the teacher provided the students the opportunity to make oral presentation, to compare notes as well as learn from one another. The teacher moderated the oral presentation. Students in this group learned together and search for materials for their project topics outside the classroom. 
Effect of four teaching strategies on senior secondary students' achievement in an aspect of agricultural science Olatoye R. A \& Adekoya, Y. M.

The fourth group comprised of students in the control group. They were taught the theory and practical using lecture/traditional teaching strategy. The teaching process also lasted for six weeks and a post-test was administered to all the students in the four groups.

\section{Results}

The data collected were analyzed using ANCOVA to compare the means of the scores of the students and also Scheffe post-hoc analysis to identify the most effective strategy. The analyses of the results, which were carried out at $\mathrm{p}=0.05$ level of significance, are presented in Table 3 .

In Table 3, there is significant main effect of treatment on students' achievement in an aspect of agricultural science that is, pasture and forage crops $\left[\mathrm{F}_{3,183}=20.775 ; \mathrm{p}<0.05\right]$ while there is no significant effect of gender on students' achievement in an aspect of agricultural science that is, pasture and forage crops $\left[\mathrm{F}_{1,183}=0.469 ; \mathrm{p}>0.05\right]$. Thus, gender (whether students are males or females) does not influence on students' achievement in an aspect of agricultural science. Likewise, self-concept does not have significant main effect on students' achievement in an aspect of agricultural science (pasture and forage crops). $\left[\mathrm{F}_{1,183}=0.142 ; \mathrm{p}>0.05\right]$.

Table 3 ANCOVA of effect of treatment and moderating variables on students' achievement in an aspect of agricultural science

\begin{tabular}{llllll}
\hline Source & Type III Sum of Square & df & Mean Square & F & Sig. \\
\hline Correlated Model & 1086.846 & 16 & 67.928 & 6.549 & .000 \\
Intercept & 981.346 & 1 & 981.346 & 94.611 & .000 \\
Agric-pretest & 320.352 & 1 & 320.352 & 30.885 & .000 \\
treatment & 646.467 & 3 & 215.489 & 20.775 & $.000 *$ \\
gender & 4.869 & 1 & 4.869 & .469 & .494 \\
self-concept & 1.472 & 1 & 1.472 & .142 & .707 \\
treatment x gender & 12.580 & 3 & 4.193 & .404 & .750 \\
treatment x self-concept & 3.962 & 3 & 1.321 & .127 & .944 \\
gender x self-concept & .105 & 1 & .105 & .010 & .920 \\
treatment x gender x & & & & & .610 \\
self-concept & 18.995 & 3 & 6.332 & & .609 \\
Error & 1898.149 & 183 & 10.372 & & \\
Total & 31761.000 & 200 & & & \\
Corrected Total & 2984.995 & 199 & & & \\
\hline
\end{tabular}

*Significant $(\mathrm{p}<0.05)$

Two-way interaction effect of treatment and gender does not have effect on achievement in pasture and forage crops $\left[\mathrm{F}_{3,183}=0.404 ; \mathrm{p}>0.05\right]$. Since the main effect of treatment is significant but the interaction effect with gender is not significant, it then means that the treatment does not depend on gender to be effective. In other words, the treatment is not gender sensitive and will be effective irrespective of students' gender. Also, two-way interaction effect of treatment and self-concept on students' achievement in an aspect of agricultural science is not significant $\left[\mathrm{F}_{3,183}=0.127 ; \mathrm{p}>0.05\right]$. This implies that the treatment will be effective irrespective of student self-concept (either high or low). Similarly, gender and self-concept have no significant interaction effect on students' achievement in an aspect of Agricultural Science [ $\mathrm{F}_{1}$, $183=0.010 ; \mathrm{p}>0.05]$. 
Three-way interaction effect of treatment, gender and self-concept has no significant effect on students' achievement in an aspect of Agricultural Science $\left[\mathrm{F}_{3,183}=0.610 ; \mathrm{p}>0.05\right]$. Thus, the treatment will work irrespective of students' gender and self-concept. In summary, all the null hypotheses are being upheld except hypothesis one that states: there is no significant main effect of treatment on students' achievement in an aspect of Agricultural Science (Pasture and Forage Crops).

Table 4 Univariate tests of the mean scores of the three groups

\begin{tabular}{llllll}
\hline & Sum of Squares & Df & Mean Square & F & Sig \\
\hline Contrast & 646.467 & 3 & 215.489 & 20.775 & $0.000^{*}$ \\
Error & 1898.149 & 183 & 10.372 & & \\
\hline *Significant $(\mathrm{p}<0.05)$ & & & &
\end{tabular}

It is not enough to establish the significant main effect of treatment on students' achievement. It is important to find out if differences exist among the treatment groups. In table 4 above, there is significance difference in the students' mean scores among the groups; demonstration, peertutoring, project-based and lecture strategies. [F3, $183=20.775 ; \mathrm{p}<0.05]$. Thus, students performed significantly at different levels in the three groups. This indicated that the treatment may not be equally effective. It is therefore important to compare the three groups two-by-two to find out the group(s) that cause(s) the difference. This is why the next table (table 5) is important.

Table 5: Pair wise Comparisons of the Four Groups

\begin{tabular}{lllll}
\hline (I) treatment $(\mathbf{J})$ treatment & Mean Difference (I-J) & Std. Error & Sig. \\
\hline Peer-Tutoring & lecture & -.567 & .700 & .419 \\
& demonstration & $-2.410^{*}$ & .666 & .000 \\
\multirow{4}{*}{ Demonstration } & project-based & $-5.095^{*}$ & .729 & .000 \\
& lecture & $1.842^{*}$ & .704 & .010 \\
& Peer-tutoring & $2.410^{*}$ & .666 & .000 \\
\multirow{5}{*}{ Project } & project-based & $-2.685^{*}$ & .733 & .000 \\
& lecture & $4.528^{*}$ & .701 & 000 \\
& Peer-tutoring & $5.095^{*}$ & .729 & .000 \\
& demonstration & $2.685^{*}$ & .733 & .000 \\
\hline
\end{tabular}

*The mean difference is significant at the 0.05 level

The essence of pair wise comparisons is to explain the cause of the significant difference reported in table 4. In table 5, there is pair wise comparison. The groups are compared two-bytwo. There is no significant mean difference between peer-tutoring and lecture strategies. There is a significant difference between demonstration and lecture strategies; demonstration strategy is significantly better. Likewise, there is a significant difference between project and lecture strategies with project strategy significantly better than lecture strategy.

There is also a significant difference between demonstration strategy and peer-tutoring teaching strategy; demonstration strategy is significantly better. In the same vein, there is also a significant difference between project and peer-tutoring teaching strategy with project strategy being significantly better than peer-tutoring strategy. Similarly, there is also significant difference between project strategy and demonstration teaching strategy with project strategy 
Effect of four teaching strategies on senior secondary students' achievement in an aspect of agricultural science Olatoye R. A \& Adekoya, Y. M.

being significantly better than demonstration strategy. The findings in Table 6 are graphically presented in Figure 1.

Table 6: Mean Scores of Male and Female Students in the Four Groups

\begin{tabular}{llcc}
\hline Treatment & Gender & Mean & Std. Error \\
\hline Peer-Tutoring & female & 10.312 & .711 \\
& male & 9.578 & .620 \\
Demonstration & female & 12.795 & .665 \\
& male & 11.914 & .695 \\
Project-based & female & 15.119 & .806 \\
& male & 14.961 & .670 \\
\hline
\end{tabular}

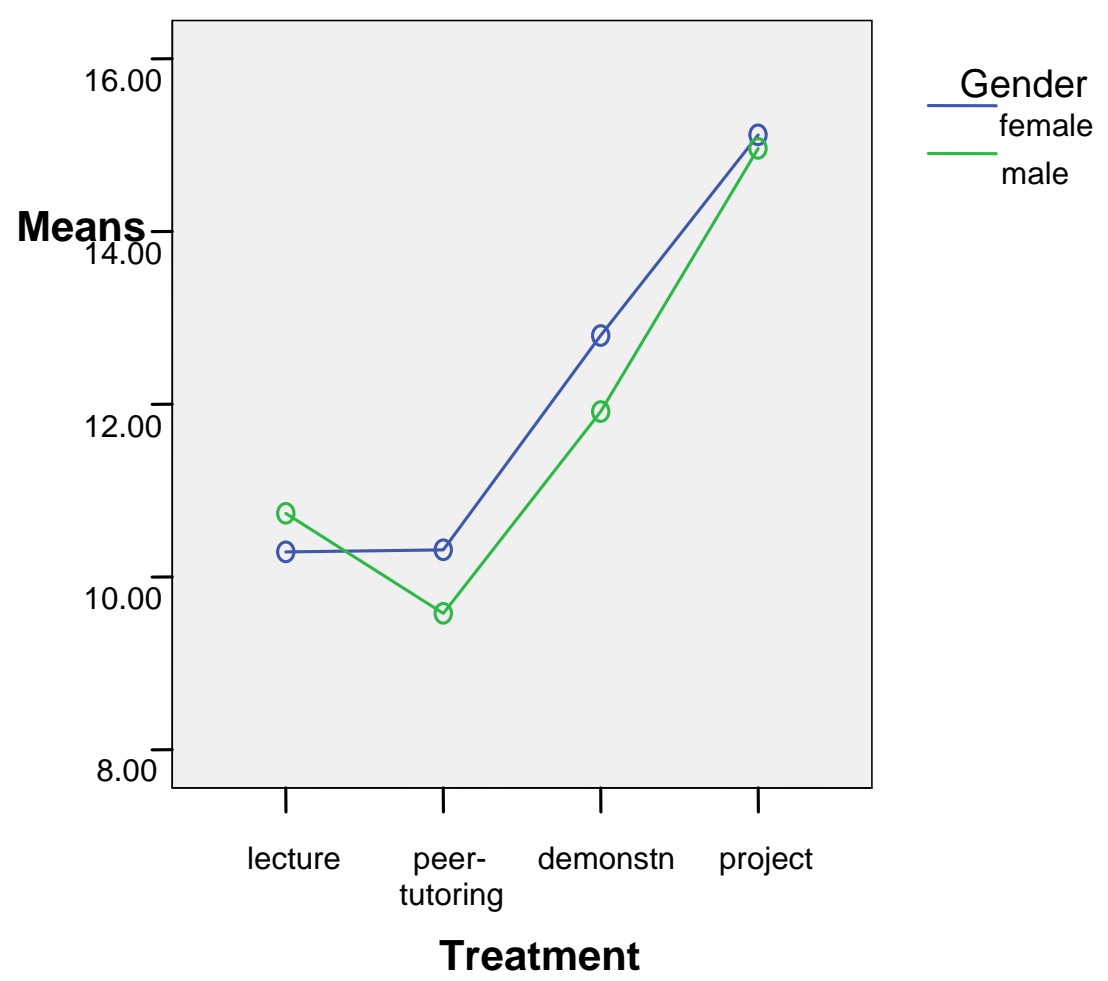

Figure 1 Mean plot of interaction effect of treatment and gender

In Figure 1 above, project strategy is the best strategy of teaching pasture and forage crops in Agricultural Science. Besides lecture strategy, female students performed better than male students in the other groups (project, demonstration and peer-tutoring). However, the difference in male and female students' achievement is not significant according to the presentation earlier given in table 3. The findings in Table 7 above are graphically presented in Figure 2. 
Table 7 Mean Scores of Students with High and Low Self-concept in the Four Groups

\begin{tabular}{llll}
\hline Treatment & \multicolumn{1}{c}{ Self-Concept } & Mean & Std. Error \\
\hline peer-tutoring & low self-concept & 9.843 & 0.652 \\
& high self-concept & 10.047 & 0.681 \\
demonstration & low self-concept & 12.304 & 0.775 \\
& high self-concept & 12.405 & 0.575 \\
Project-based & low self-concept & 15.149 & 0.548 \\
& high self-concept & 14.931 & 0.889 \\
\hline
\end{tabular}

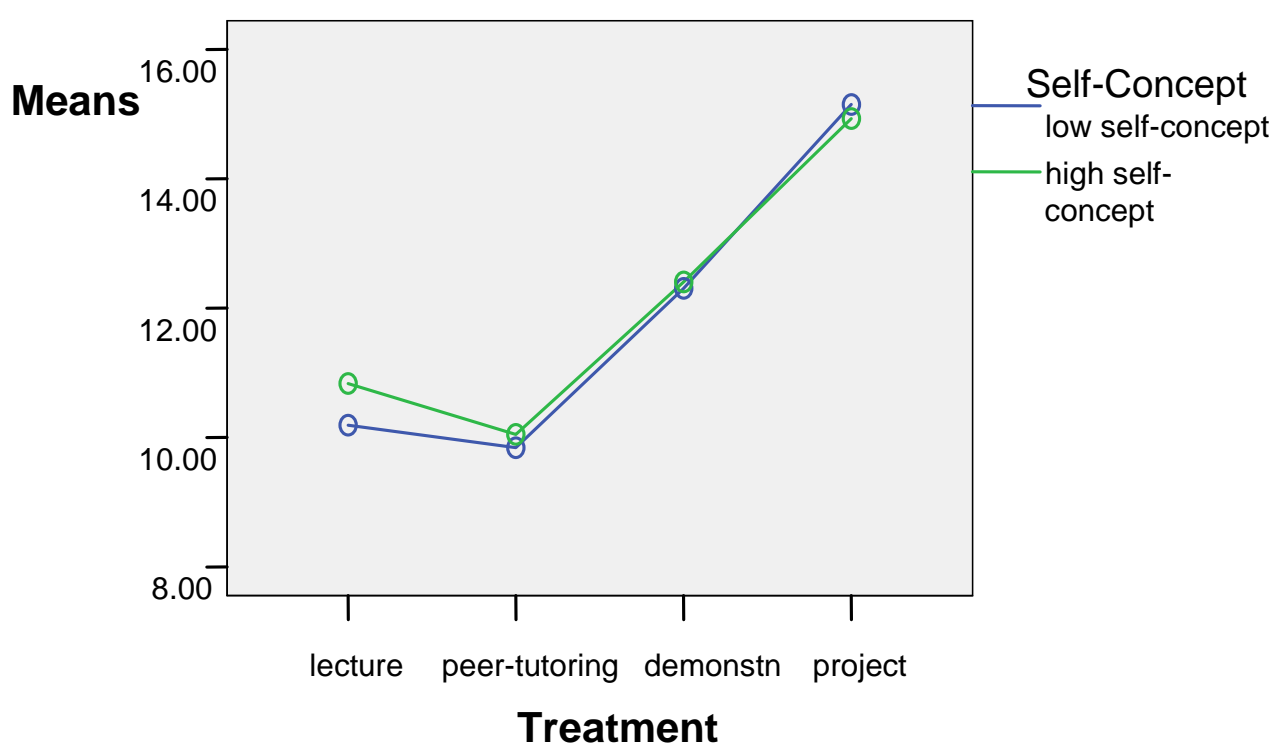

Figure 1: Mean plot of interaction effect of treatment and self-concept

In Figure 2 above, project method is the best strategy of teaching pasture and forage crops in Agricultural Science. Students with high self-concept have about the same level of achievement in each of the teaching strategies except lecture strategy. It should be noted that the two-way interaction effect of treatment and self-concept is not significant as earlier presented in Table 3. The findings in Table 8 above are graphically presented in Figure 3

Table 8 Mean Scores of the Male and Female Students with high and low self-concept

\begin{tabular}{|c|c|c|}
\hline Self-Concept & Mean & Std. Error \\
\hline $\begin{array}{r}\text { Female low self-concept } \\
\text { high self-concept }\end{array}$ & $\begin{array}{l}12.013 \\
12.244\end{array}$ & $\begin{array}{l}.469 \\
.548\end{array}$ \\
\hline $\begin{array}{ll}\text { Male } & \text { low self-concept } \\
\text { high self-concept }\end{array}$ & $\begin{array}{l}11.730 \\
11.864\end{array}$ & $\begin{array}{l}.465 \\
.450\end{array}$ \\
\hline
\end{tabular}




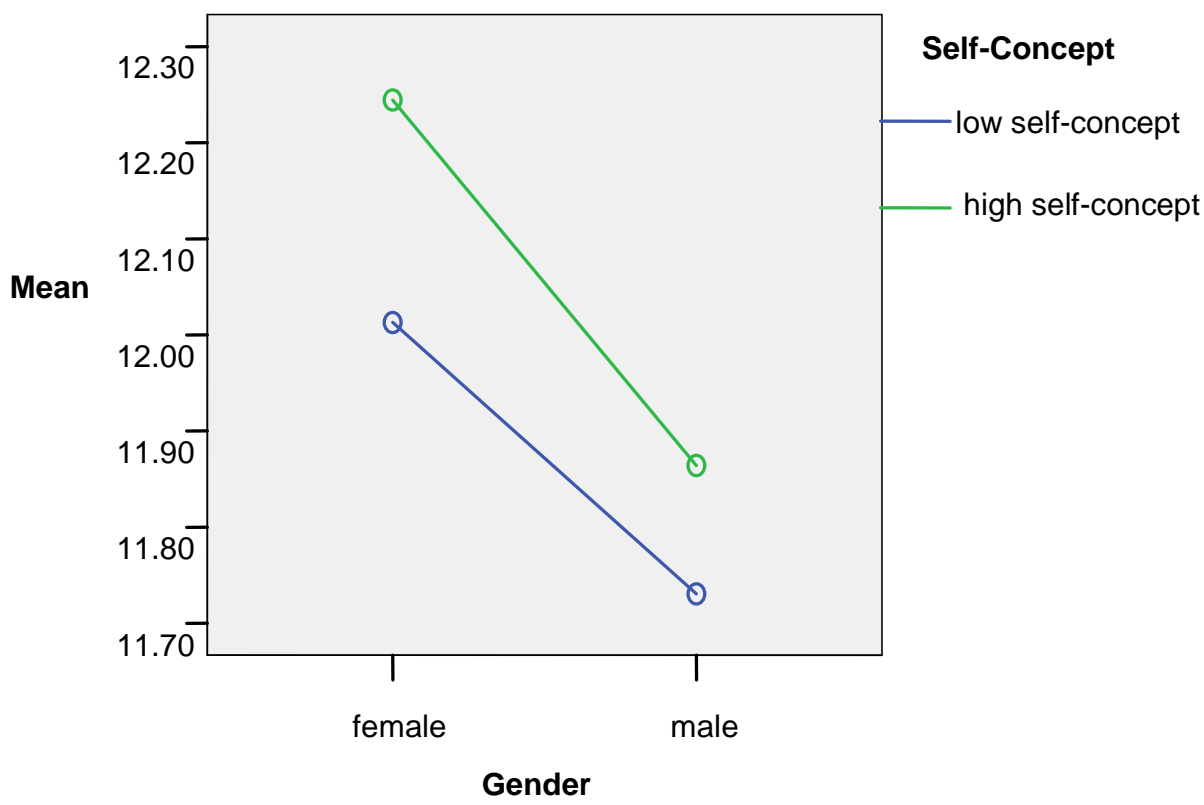

Figure $3 \quad$ Mean plot of interaction effect of gender and self-concept

In Figure 3 above, female students with high self-concept have higher scores in an aspect of Agricultural Science than female students with low self-concept. It should be noted however that the there is no significant interaction effect of gender and self-concept on achievement in an aspect of Agricultural Science.

\section{Discussion}

The analyses and results of this study showed that the project-based strategy brought about the most significant change in the achievement of students. This might be due to the social interaction and friendliness that the project-based strategy provided for the students. Students in the project-based strategy group were better motivated to learn; this might be as a result of the discipline of having to and respect the opinion of others during discussion having discovered that knowledge does not belong to only a person. Webb (1998) opined that the more interactions there among students the better their performance. The project-based learning encourages collaboration in some form, either through small groups, student-led presentations, or wholeclass evaluations of project results (Buck Institute for Education, BIE, 2002). Project-based strategy of learning shares some overlapping characteristics with inquiry-based or experimental learning and appears to be an equivalent or slightly better model for producing gains in academic achievement, although results vary with the quality of the project and the level of student engagement (Dohn \& Wagne, 1999; Buck Institute for Education, BIE, 2002). 
Furthermore, the project and peer-tutoring strategies also yielded a significant difference when compared with the control group. The lecture method is the most widely used form of presentation and may be combined with other teaching strategies to give added meaning and direction. The students in this study are conversant with project-based and peer-tutoring strategies as their teachers often used them because of their adaptability to many different settings, including either small or large groups (Blair, Schwartz, Biswas, Leelawong, 2007).

Dynamic Flight (2003) gave an illustration on selection of appropriate teaching method(s) for science lesson. Teaching methods should be compared to maintenance technician's box. The instructor's tools are the teaching methods. Just as the technician uses some tools more than the others, there will be times when a less used tool will be the exact instrument needed for a particular situation. The instructor's success is determined to a large extent by the ability to organize materials and to select and utilize teaching methods most appropriate to a particular lesson.

In selecting teaching method(s) for a science class, Abdullahi (1982) enjoined the teacher/instructor to consider the following factors:

- The learners' age, their previous knowledge on the topic and their ability.

- The method should be suitable to the topic being taught.

- The science teacher should select the method he/she can effectively handle.

- The time the lesson will take place.

- The size of the class where the lesson is being taught.

- The resources that are at the disposal of the teacher.

Thus the fact that a method is suitable for the teaching of pasture and forage crops does not mean it will be a suitable topic for teaching another topic even in the same subject. There are times Agricultural science teacher may need to combine different methods to teach a particular topic. Olatoye (2006) identified methods that can be used to teach science effectively. These methods include demonstration, discussion, individualized, field trip method and computer-based instruction.

\section{Conclusion}

Learning agricultural science leads to the development of thinking skills and understanding the other sciences. Project-based teaching strategy has been found challenging but can be evaluated as a rewarding exercise and an overall success as a result of its capability to help the students learn to develop the ability to think critically and analytically and a high degree of independence is required as the students have to learn how to identify resources and how to communicate effectively and this no doubt helped the learners to comprehend abstract concepts.

The project-based teaching strategy in this paper produces significantly better performance in the Agricultural Achievement Test than the peer-tutoring, demonstration and lecture teaching strategies. Thus, project-based teaching strategy is an effective mode of instruction for students in the secondary schools. However, a teaching method is seldom used by itself. In a typical lesson, an effective instructor normally uses more than one method. The findings of this study has revealed that peer-tutoring, demonstration and project-based teaching strategies can be used for teaching and learning processes depending on the topic but project teaching strategy is the most effective in teaching pasture and forage crops because it afforded the students the 
Effect of four teaching strategies on senior secondary students' achievement in an aspect of agricultural science Olatoye R. A \& Adekoya, Y. M.

opportunity to study on their own. Thus, while satisfying the attempt to improving the utilization of the regular school hours of the students; the provision of opportunity for learning by "doing" is a practice that could be adequately employed in our classrooms. This paper concludes that the use of project-based strategy of teaching should be embraced by all secondary school science teachers. Learning is deeper and more meaningful when students are involved in constructing their own knowledge, if students are given the opportunity to select a topic that interests them within the required content framework and then they are responsible for creating their project plan.

\section{Recommendations}

In view of the results of these findings and conclusions reached in this paper, the following recommendations are hereby offered:

- Government should introduce the concept of professionalism to give room for proper and relevant retraining to science teachers. Agricultural science teachers should be given onthe-job training opportunities such as short-term courses, seminars, and workshops to enable the teachers to update their knowledge. This will help them to constantly keep abreast with the ever-changing scientific knowledge and various modern strategies of teaching science.

- Students in the senior secondary school should be given project topics to work on in the form of term paper which should be guided by teachers and submitted at the end of the last term in the final year.

\section{References}

Abdullahi, A. (1982). Science Teaching in Nigeria. Ilorin: Atoto Press Limited.

Barron, B.J.S., D.L. Schwartz, N.J. Vye, A.Moore, A.Petrosino, L.Zech, and J.D. Bransford (1998): "Doing with Understanding: Lessons from Research on Problem- and ProjectBased Learning", J. Learning Sciences, 7 (3\&4), 271-312.

Biajone, J. (2006). Promoting positive attitudes towards statistics in pedagogy students through project work. ICOTS-7. State University of Campinas, Brazil.

Binnie,N.S.(2002). Neil Binnie's Statistics Resource, New Zealand: Auckland University of Technology. Retrieved December $3^{\text {rd }} 2009$ at http://www.aut.ac.nz/depts./stats/....

Blair, K., Schwartz, D.L., Biswas, G., \& Leelawong, K. (2007). Pedagogical agents for learning by teaching: Teachable Agents. Educational Technology, 47(1), 56-61.

Blumenfeld,P.,Soloway,E.,Marx,R.,Krajcik,J.Guzdial,M.\&Palincsar,A,(1991).Motivating project-based Learning. Educational Psychologist, 26(3\&8), 369-398

Boud, D., Cohen, R. \& Sampson, J. (2001). Peer-learning in higher education: Learning from and with each other, London Kogan Press.

Bransford, J. D. \& Schwartz,D.L.(1999).Re-thinking Transfer: A simple proposal with multiple implication, Review of Research in Education,24(1),61-100.

Buck Institute for Education, BIE. (2002). Project-based Learning with Technology(PBL+T) for Higher Education. Retrieved on $3^{\text {rd }}$ December 2009 at: http://www.bie. org/pbl/index.php

Carrier, K. (2005).Key issues for teaching learners in the classrooms, Middle School Journal, $37(4), 17-24$. 
Dohn, H.N. \& Wagner, K.D.(1999).Strategies and methods of teaching in contemporary higher education with reference to project work. Innovations in Education and Training International, 36 (1), 285-91.

Dynamic Flight (2003).Teaching Methods, Available at http://www.dynamicflight/avcfibook/methods Retrieved 12th January,2003.

Education Week (2001). Technology Counts 200: The New Divides. Education Week, Vol. XX, No. 35.

Erinosho, S. Y. (1997). Female participation in science: An analysis of secondary school science curriculum materials in Nigeria. Abridged ResearchReport No 29, Published by Nairobi Academic of science Publisher, Kenya.

Holubara, R. (2008). Effective teaching methods: Project-based learning in Physics. US-China Education Review, 5(12), 27 - 35.

Huitt, W. (2004). Self-concept and self-esteem. Valdosta State University: Educational Psychology Interactive, Retrieved $6^{\text {th }} \quad$ May 2009 from Http:// www.chiron.valdosta.edu/whuitt/col/regsys/self.html

Johnson, D. M. Wardlow, G. W \& Franklin, T.D (1998). Methods of reinforcement and student gender effect on achievement in agricultural science Education. Journal of Agricultural Education, 39, (4), 18-27.

Kumar, W.S. \& Morris, J. (2005). Predicting scientific understanding of prospective elementary teachers: Role of Gender, education level, courses in science and attitude toward science and mathematics, Journal of Science Education and Technology, 14(4), 387-391.

Lang, H. G. (2006). Science education for deaf students: Priorities for researcher and instructional development, New York: Rochester Institute for the Deaf.

Lee, M.M. (1998). Gender differences in young Adolescents' Mathematics and Science achievement, Childhood Education.2, 123-134.

Longaretti, L., Godinho, S., Parr, G., Wilson, J. (2009). Rethinking Peer-Teaching, The University of Melbourne Retrieved 21 ${ }^{\text {st }}$ July, 2009.

Madrid, N., Terry, B., Greenwood, C. Whaley, M. \& Webber, N. (1998). Active Versus Passive Peer-tutoring: Teaching Spelling to At-Risk students. Journal of Research and Development in Education. 31(4), 236-244.

Newby, T. J. Stepich, D. A., Lechman, J. D \& Russel J. D. (1996). Introduction to Instructional Technology, Instructional Technology for Teaching and Learning. Englewood Cliffs, New Jersey: Educational Technology Publications. Pp 48.

Olatoye, R .A. \& Afuwape, M.O. (2004). Emergent issues in enhancing teaching and learning of science in schools. In: O.A Afemikhe and J.G Adewale (Eds). Issues in Educational measurement and Evaluation in Nigeria, Published by Institute of Education, University of Ibadan, Nigeria.

Olatoye, R.A (2008). Self-concept and science achievement in co-educational and single-sex Junior Secondary School in Ogun State Nigeria, Review of Higher Education and SelfLearning, 1 (1), 69-74 Available at: www.intellectbase.org.

Olatoye,R.A.(2006). Raising the standard of science teaching for great and dynamic economic development in Nigeria, Journal of Qualitative Education, 2(1), 39-46. 
Effect of four teaching strategies on senior secondary students' achievement in an aspect of agricultural science

Olatoye R. A \& Adekoya, Y. M.

Prpric, J.K. \& Hadgraft, R.G. (2009). What is problem-based learning? Retrieved on $3^{\text {rd }}$ December,2009 at http://www.dlsbweb.rmit.edu.au/eng/beng0001/learning/strategy

Sanhez, F.J.P. \& Roda, M, D. S. (2006). Electronic Journal in Psychology and Psychopadagogy, $1(1), 95-120$.

Sotonade, O. A. T. (2004). Gender Issues as perceived by Nigeria parents. Journal of Education Focus, 5, 68-80.

Tamir, P. (1990). Ethnic origins and science learning of Israel High school students, Studies in Educational Evaluation, 16, 373-397.

Telecsan, B. L., Slaton, D. B. \& Stevens, K. B. (1999). Peer-tutoring: Teaching students with Learning Disabilities to Deliver Time Delay Instruction, Journal of Behavioural Education, 9 (2), 13-154.

Tournaki, N. \& Criscitiello, E. (2003): Using peer-tutoring as a successful part of behaviour management. Teaching Exceptional Children. 36(2). Retrieved February 21, 2006 from EBSCO database.

Uhumuavbi, J. A. \& Mamudu, J. A. (2009). Relative effects of programmed instruction and demonstration methods on students' academic performance in science, College Students Journal, 2(4), 46-57.

Webb, M. (1998).Peer helping relationships in urban schools, Equity and Choice, 4(3), 35-48.

William, S.M. (1992).Putting case-based instruction into context: Examples from legal and medical education. The Journal of the Learning Sciences, 2(4)367-427.

Wood, W.B \& Gentile, J.M. (2003). Teaching in a Research Context. Science, 302:1510. 